\title{
О НЕКОТОРЫХ ВОПРОСАХ УСМОТРЕНИЯ И ПОЗНАНИЯ В УГОЛОВНОМ ПРОЦЕССЕ
}

\section{OVERVIEW OF ISSUES ON DISCRETION AND COGNITION IN CONTEMPORARY CRIMINAL PROCEDURE}

\section{R. Gaprindashvili}

Summary. Uncertainty issues of some concepts are rather acute in contemporary jurisprudence. It is especially the case of nonlinear perception questions about those concepts that do not undergo materialism of individual stereotypical standardization.

Through this article attempts are made to formulate an opinion on certain issues and intricacies of a correct understanding of cognition questions and discretion in criminal procedure.

Criminal procedure has its own characteristics related to the specificity of the process course.

That specificity of cognition process both in science field or in other human activities is primarily determined by the object of cognition as well as by the subject and conditions under which the process takes place.

Keywords: criminal procedure, cognition, discretion.
Гаприндашвили Резо Тенгизович К.ю.н., доцент, ФГБОУ ВО «Государственный университет по землеустройству», Москва rtgaprindashvili@yandex.com

Аннотация. В современной юриспруденции вопрос неопределенности некоторых понятий носит довольно острый характер. Особенно это касается вопросов «нелинейного» восприятия тех терминов, которые не проходят через материализм индивидуальных стереотипных стандартизаций.

В статье представлено мнение об определенных вопросах и тонкостях правильного понимания вопросов познания и усмотрения в уголовном процесce.

Уголовно-процессуальное познание имеет свои особенности, которые связаны со спецификой протекания этого процесса. Специфика процесса познания в той или иной области науки, в той или иной отрасли деятельности человека обусловлена прежде всего объектом и предметом познания, а также субъектами познания и теми условиями, в которых этот процесс протекает.

Ключевые слова: уголовный процесс, познание, усмотрение.
B современном мире вопрос неопределенности понятий носит довольно острый характер. Например, достаточно трудно дать исчерпывающие определения для терминов "усмотрение" и "познание". Что такое познание и усмотрение в классическом понимании? Обратимся к словарю. «Познание - процесс действия или знание чего-либо, осведомленность в чем-либо» [1]. «Усмотрение - процесс действия по значению; заключение, решение; действие, решение или склонность действовать, решать по собственному желанию, а не по закону» [1].

Установление обстоятельств совершенного преступления является основным направлением уголовно-процессуальной деятельности. В данном случае, процесс установления обстоятельств носит абсолютно познавательный характер.

Выявление и сбор информации о преступлении служит условием эффективной познавательной деятельности. Если этой информации нет, то уголовно-процессуальное познание из познания, основывающегося на фактической информации, которая служит основой для дела, превращается в абстрактные умозаключения. И в таком случае не остается возможностей для вынесения обоснованного процессуального решения.

В классической доктрине Российской юриспруденции уголовно-процессуальное познание рассматривается как отдельное направление познания действительности, которое вместе с тем происходит по закономерностям, свойственным всем остальным видам познавательной деятельности. Вышесказанное может восприниматься с дуальным характером. Субъекты познания, учитывая устанавливающие обстоятельства дела, выясняют отдельные признаки, факты и свойства тех или иных объектов с помощью чувственного восприятия. На основе этой информации субъекты познания рационально сопоставляют все обстоятельства и логически осмысляют объект (преступление).

В более широком понимании, раскрытие и расследование преступления, а также классическое судебное рассмотрение уголовного дела олицетворяют собой 
два основных этапа общего и единого познавательного процесса. На каждом этапе познания основное внимание направлено на получение необходимых сведений о конкретном событии преступления. Субъект познания выявляет его структуру, состав, основные и факультативные элементы, корреляцию между ними, а также связь отдельных элементов преступления с обстановкой, в которой оно было совершено.

Фундаментом для описанного выше познания является поиск, сбор, разработка, изучение, обследование и оценка информации о механизме преступления. В данном случае методы и средства должны обеспечивать соответствие нормам и объективность информации, которую субъекты познания выясняют. Есть важное отличие между познанием в уголовной деятельности и других областях. Оно состоит в том, что "объективность" в данном случае воспринимается не только как объективность самого процесса получения знаний, но и как объективность представления обстоятельств преступления в материалах уголовного дела.

Также стоит отметить, что при оценке собранной информации субъект познания должен уметь различать истинную и ложную информацию. Для того, чтобы строить версии событий, изучать их и проверять важно умение разделять правдоподобные версии от истинной модели произошедшего, и это является основным фактором, ведущим к объективности познания.

Уголовно-процессуальное познание имеет свою дистинктивность, связанную с индивидуальными особенностями конкретного процесса. Специфика процесса познания в разных областях науки, независимо от конкретной отрасли, зависит от объекта и предмета познания, а также от субъекта познания и той среды, в которой процесс познания протекает.

В уголовно-процессуальном праве объект познания состоит из разных событий, явлений, деяний людей, в отношении которых существует подозрение, что они являются общественно опасными. Цели и задачи уголовно-процессуального познания также содержат свою специфику. Вынести решение по конкретному делу - это основная цель, которая стоит перед следователем, прокурором и судьей. Данное решение является определенным, заранее определенным законом видом государственной деятельности - судопроизводством [3].

Условия осуществления уголовно-процессуального познания обладают следующими особенностями, помимо факторов, упомянутых выше. К ним относится:

1. Ретроспективность уголовно-процессуального познания.
2. Уникальность объекта познания - совершенного преступления и предмета - информации о преступлении.

3. Осуществление познавательной деятельности специально уполномоченными на то законом субъектами.

4. Ограниченность познания во времени процессуальными сроками.

5. Использование в качестве средств познавательной деятельности лишь тех, которые прямо предусмотрены законом либо не противоречат закону.

6. Наличие обязательных средств познавательной деятельности, использование которых прямо предписывается законом в ряде специально оговоренных случаев.

7. Необходимость принятия решения по итогам познавательной деятельности [3].

Познание в досудебных стадиях уголовного судопроизводства имеет отличительные черты, которые обусловлены тем, что необходимо:

1. Исследовать событие, которое обладает признаками преступления.

2. Решать вопросы о том, было ли деяние преступным или нет, есть ли поводы и основания для возбуждения уголовного дела.

3. Выдвигать версии о личности виновного, разыскивать и изобличать его в совершении преступления.

4. Собирать, исследовать и оценивать доказательства, формулировать окончательные выводы о структуре и характере преступления.

Выводы, сделанные после предварительного расследования, имеют большое самостоятельное значение. Но в судебной стадии они используются только как одна из версий произошедшего. Участники судебного разбирательства исследуют доказательства, представленные в уголовном деле. Они также в определенной степени изучают события, в которых есть признаки преступления.

В суде познание происходит в процессуальных условиях, которые отличаются от условий предварительного расследования. Из-за этого меняется характер частных особенностей процесса познания в судебной стадии по сравнению с предыдущими этапами уголовного судопроизводства.

Сбор и обработка информации о преступлении смешанное процессуально-криминалистическое содержание. Криминалистика в этом случае является инструментом в контексте деятельностного подхода и служит тому, чтобы уголовное судопроизводство выполнило 
свое назначение. Эту концепцию В.Я. Колдин разработал в 1980-е годы, и она получила название «информационно-познавательной деятельности». Согласно его идее «предметом криминалистики является структура информационно-познавательной деятельности по раскрытию, расследованию и предупреждению преступлений и обеспечивающие ее оптимизацию легальные организационные, технические и тактико-методические средства, приемы и технологии» [4].

В середине 1990-х г.г. В.А. Образцов развивал данное направление и предложил концепция криминалистической поисково-познавательной деятельности (практического следоведения) в уголовном судопроизводстве, её технологиях и средствах. Эти идеи были близки к концепции В.Я. Колдина, но в отличие от них они имели узкую направленность на практическую деятельность и сводили ее к технологиям розыскной деятельности и предварительного расследования. При этом термин «поисково-познавательная деятельность» является бо- лее предпочтительным, чем «информационно-познавательная деятельность». С позиции деятельностного подхода именно поисковая деятельность корректнее отражает сущность деятельности субъектов уголовного судопроизводства и одновременно является начальным этапом познавательной деятельности и создает информационную основу правоприменительной деятельности в уголовном судопроизводстве [5].

Следовательно, быть обнаруженной может только та информация, которая поддаётся смысловой интерпретации в качестве объекта познания, то есть смысл которой может быть понят, с помощью существующих на данном уровне знаний процессуальных и криминалистических средств. Соответственно, усмотрение субъектами поисковой деятельности реализуется через объективное познание. Чем шире круг таких средств, доступных, известных субъекту познания, тем шире круг обнаруживаемых фактов и выше вероятность истинности.

\section{ЛИТЕРАТУРА}

1. Ефремова Т. Ф. Современный толковый словарь русского языка: В 3 т.- М.: АСТ, Астрель, Харвест, 2006, с. 47, с. 171.

2. Коршунова 0. Н. Роль теории познания в уголовном судопроизводстве. Криминалист, 2011 № 1 С. 68.

3. Криминалистика / Под ред. В. А. Образцова.- М.: Юристь, 1997, с. 49, с.113

4. Криминалистика. Аверьянова Т. В., Белкин Р. С.:- - М, Норма, 2000 г., с. 244

5. Лупинская П. А. Решения в уголовном судопроизводстве. Их виды, содержание и формы.— М., 1976. — С. 18. 